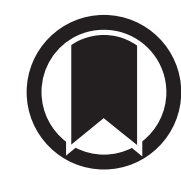

CrossMark

\title{
Znaczenie tomografii komputerowej w diagnostyce nowotworów wątroby
}

\section{Importance of computed tomography in diagnosis of liver cancer}

\author{
Aleksandra Głodek ${ }^{1}$ \\ ${ }^{1}$ Uniwersytet Medyczny im. Karola Marcinkowskiego w Poznaniu
}

\section{Streszczenie}

Badania obrazowe są integralną częścią diagnostyki chorób nowotworowych. Do badań tych zalicza się między innymi: ultrasonografię (USG), tomografię komputerową (TK) oraz rezonans magnetyczny (MRJ). Wykonanie ultrasonografii jest stosunkowo proste i tanie. W oparciu o przeprowadzone badanie USG, radiolog zazwyczaj jest w stanie ocenić wielkość wątroby, echogeniczność, czy obecność struktur patologicznych w jej obrębie. W celu uzyskania bardziej szczegółowej wiedzy na temat zmiany, pacjentom zaleca się badanie tomograficzne lub badanie rezonansem magnetycznym z użyciem środka kontrastowego. TK wykorzystuje promieniowanie jonizujące, dzięki czemu powinna być zlecana według ściśle określonych wskazań. W trakcie jednego badania wykonuje się wiele zdjęć rentgenowskich, co istotnie wpływa na dawkę zaabsorbowaną w ciągu roku przez pacjenta. Nowotwory wątroby stanowią 7\% wszystkich nowotworów. Do czynników zwiększających ryzyko zachorowania na nowotwór wątroby zalicza się między innymi marskość wątroby, zakażenie wirusem B lub C, a także nadużywanie alkoholu. Badanie TK pozwala na zdefiniowanie charakteru zmiany, a także jest pomocne w określeniu jej zasięgu. Procedura ta umożliwia opisanie stosunku guza do struktur położonych w pobliżu. MRJ może być alternatywą w przypadku braku uzyskania satysfakcjonującej wiedzy na temat nowotworu w badaniach poprzednich.

\begin{abstract}
Diagnostic imagining is an integral part of the diagnosis of cancer. That examination includes: ultrasonography, computed tomography and magnetic resonance imaging. Ultrasonography is relatively simple and cheap. Using ultrasonography, the radiologist is usually able to assess the size of the liver, echogenicity or the presence of pathological structures within the liver. To receive a better knowledge of the lesion, patients are referred to computed tomography or magnetic resonance imaging using a medical contrast medium. Computed tomography uses ionizing radiation, therefore, it should be prescribed according to strictly defined indications. During the examination, the device performs a lot of scans, which significantly influences the dose absorbed by the patient per year. Liver cancer accounts for $7 \%$ of all cancers. Risk factors include the liver cirrhosis, hepatitis B or C, and alcohol abuse. CT allows to define the nature of the lesion and is helpful in determining its extent. The procedure makes it possible to assess the tumor relation to neighboring structures. Magnetic resonance can be an alternative should the previous examinations fail to provide satisfactory knowledge about the tumor.
\end{abstract}


Stowa kluczowe: nowotwór wątroby; diagnostyka obrazowa; tomografia komputerowa

Keywords: liver cancer; diagnostic imaging; computed tomography

\section{Wstęp}

Diagnostyka obrazowa jest ważną częścią nauk medycznych, ponieważ ukazuje zmiany patologiczne zachodzące $\mathrm{w}$ organizmach żywych. $\mathrm{Z}$ roku na rok wzrasta zainteresowanie badaniami tego typu, co wynika między innymi z rozwoju technologii, ale także potrzeb pacjentów. Społeczeństwo starzeje się, a to sprzyja rozwojowi wielu chorób. Tomografia komputerowa jest jedną z metod, na jakie może zdecydować się lekarz kierujący pacjenta na badanie obrazowe. Zwraca się uwagę na uzasadnione wykonywanie badań tomograficznych - cel badania powinien być jasno określony, tak by nie narażać pacjentów na ekspozycję przy braku wskazań klinicznych. Na podstawie danych zawartych w książce „Wytyczne dla lekarzy kierujących na badania obrazowe" typowa dawka skuteczna wyrażona w mSv w przypadku skanowania jamy brzusznej wynosi 5,6 mSv, natomiast przy badaniu jamy brzusznej z miednicą 6,7 mSv [1]. Badanie TK powinno nieść istotne informacje dla rozpoznania klinicznego. Ważne jest szczegółowe wypełnienie skierowania, ponieważ w oparciu o skierowanie dobierany jest zasadny protokół badania oraz ustalany jest sposób postępowania z pacjentem. Wpływa to także na zalecenia dedykowane pacjentom przed badaniem (np. prośba o bycie na czczo).

Rzetelnie opracowane skierowanie ułatwia elekroradiologowi pracę z pacjentem, a także sprawia, że jakość przeprowadzonej procedury może być wyższa niż w przypadku niedoprecyzowania wskazań. Dokładny opis podejrzeń klinicysty zwiększa czujność elektroradiologów oraz radiologów w aspekcie detekcji przypuszczalnych zmian.

\section{Dane epidemiologiczne - nowotwory wątroby w Polsce}

Nowotwory wątroby stanowią 7\% wszystkich zachorowań na nowotwory. Występują u kobiet 3 razy rzadziej niż u mężczyzn. Częściej wykrywane są u pacjentów żyjących w krajach słabo rozwiniętych pod kątem ekonomicznym. W 2010 r. zdiagnozowano w Polsce 1416 nowotworów wątroby. W tej grupie znajdowało się 829 mężczyzn i 587 kobiet. W 2010r. z powodu nowotworu wątroby na terenie Polski zmarło 2015 osób [2].

Przerzuty do wątroby są częściej diagnozowane niż pierwotne nowotwory wątroby.

\section{Czynniki ryzyka}

Do czynników zwiększających ryzyko zachorowania na raka wątroby zalicza się:

- marskość wątroby;

- zakażenie wirusem wątroby typu B, C;

- nadużywanie substancji alkoholowych;

- ekspozycja na mykotoksyny;

- stłuszczenie wątroby;

- metaboliczne choroby wątroby tj. hemochromatoza [3].

\section{Objawy kliniczne nowotworu wątroby}

Nowotwory pierwotne wątroby we wczesnym stopniu zaawansowania najczęściej nie dają charakterystycznych symptomów.

Chorzy mogą skarżyć się na ból w jamie brzusznej - zwykle występuje on w okolicy prawego podżebrza. Ponadto u chorych mogą pojawić się zaparcia, wzdęcia, biegunki oraz utrata wagi z powodu braku apetytu. W późniejszych etapach rozwoju nowotworu, wątroba może ulec powiększeniu. Czasem możliwe staje się palpacyjne wyczucie guza w obrębie prawego podżebrza. U chorych z zaawansowanym nowotworem rozwija się wodobrzusze oraz niekiedy żółtaczka [4]. 


\section{Aspekt hepatomegalii - czy objaw jest charakterystyczny tylko dla nowotworu wątroby?}

W trakcie badania USG, TK oraz MRJ możliwa jest ocena wielkości wątroby. Przypadek powiększenia wątroby (hepatomegalia) może mieć różne podłoże. Hepatomegalia czasami związana jest z obecnością wady wrodzonej np. torbielowatości wątroby. Może również wynikać z niewydolności serca - wówczas jest to hepatomegalia zastoinowa. Dodatkowo hepatomegalię może wywoływać zapalenie wątroby, stłuszczenie wątroby, choroby układowe, marskość wątroby oraz nowotwory pierwotne jak i przerzuty [5].

\section{Tomografia komputerowa - opis techniki}

Tomografia komputerowa to badanie wykorzystujące promieniowaniejonizujące do obrazowania narządów wewnętrznych. Umożliwia wizualizację tkanek dzięki osłabieniu promieniowania, przechodzącego przez ciało pacjenta. Źródło promieniowania emitowane jest przez lampę rentgenowską umieszczoną wewnątrz okola aparatu. Detektory przemieszczają się w trakcie badania po okręgu, który jest prostopadły do osi długiej pacjenta. Tomograf zbudowany jest $\mathrm{z}$ przesuwnego stołu, gantry oraz komputera $\mathrm{z}$ odpowiednim oprogramowaniem. W trakcie badania dobierane jest stosowne natężenie tzw. obciążenie prądowo - czasowe [mAs] oraz napięcie. Parametry badania przekładają się na jakość otrzymywanych obrazów, a także na dawkę jaką absorbuje pacjent [6].

\section{Diagnostyka obrazowa nowotworów wątroby}

Pacjent z podejrzeniem choroby wątroby zazwyczaj w pierwszej kolejności trafia do lekarza pierwszego kontaktu lub internisty. Następnie może zostać skierowany na wizytę u hepatologa specjalizującego się w chorobach wątroby. U lekarza przeprowadzane jest badanie podmiotowe jak i przedmiotowe oraz czasami zlecane są dodatkowe procedury obrazowe. Niekiedy na samym wstępie diagnostyki obrazowej wykonywane są dwa klasyczne zdjęcia rentgenowskie tj.: przeglądowe zdjęcie przednio - tylne jamy brzusznej (łac. AP anterior - posterior) i zdjęcie klatki piersiowej w projekcji tylno-przedniej (łac. PA - posterior - anterior). W przypadku zauważenia zmiany w wątrobie większość chorych kierowana jest dalej do pracowni USG. Ultrasonografia jest metodą z wyboru w początkowej diagnostyce zmian ogniskowych dla tej lokalizacji. Wynika to m.in. z nieinwazyjności samego badania, jak i łatwości wykonania procedury. Badanie jest szybkie i stosunkowo tanie, jednak powinno być wykonywane przez osobę z odpowiednio dużą wiedzą i rzetelnym przeszkoleniem w zakresie metodyki USG. Czułość ultrasonografii w detekcji nowotworu wątroby określana jest w przedziale 75 - 90\%. Badaniem uzupełniającym jest trójfazowa tomografia komputerowa.

Dodatkowo w przypadku wątpliwości może zostać zlecony rezonans magnetyczny często z użyciem środka kontrastowego. Badaniem, które cechuje się najwyższą czułością i swoistością jest cholangiografia rezonansu magnetycznego.

Badania trójfazowe TK (tj. przed i po podaniu kontrastu) wykonuje się przy zastosowaniu odpowiedniego protokołu dedykowanego dla konkretnej lokalizacji. Wyróżnia się fazę tętniczą, żylną oraz opóźnioną (miąższową). Badanie TK rozpoczyna się od uzyskania topogramu w rzucie przednio-tylnym oraz bocznym. Na jego podstawie dobiera się zakres skanowania do dalszego badania. Całą późniejszą procedurę wykonuje się przy zeskanowaniu pacjenta przed podaniem kontrastu oraz odpowiednio po podaniu kontrastu, $\mathrm{w}$ określonych ramach czasowych od momentu wstrzyknięcia. Kontrast napływa z ustawionej przez pielęgniarkę strzykawki automatycznej. Kiedy środek kontrastowy pojawi się w wyznaczonym miejscu w naczyniu tętniczym (w przypadku badania jamy brzusznej jest to okolica aorty piersiowej), elektroradiolog podejmuje decyzję o rozpoczęciu dalszego skanowania. Na ekranie prezentuje się kolejno faza tętnicza, oraz po upływie czasu wynikającego z protokołu - faza żylna. Faza tętnicza umożliwia obrazowanie zmian bogato unaczynionych, natomiast żylna uwidacznia zmiany o ubogiej strukturze naczyniowej. Po wykonaniu obu faz można także zobrazować fazę opóźnioną ze wskazania lekarza radiologa. Po zakończeniu całej procedury specjalista w zakresie diagnostyki obrazowej opisuje badanie. Na wynik badania ma wpływ między innymi stopień wzmocnienia kontrastowego $\mathrm{w}$ pierwszej fazie badania - tj. fazie tętniczej oraz szybkość wypłukiwania kontrastu w dwóch kolejnych fazach. Tomografia komputerowa ma znaczenie w trakcie kwalifikacji do 
chirurgicznego leczenia. Pozwala na ocenę topografii zmian w naczyniach. Użyteczna jest także w aspekcie określenia wielkości zmiany, charakteru, zasięgu, oraz stosunku guza do otaczających tkanek [7].

\section{Nowotwory wątroby. Obrazy radiologiczne w wybranych metodach diagnostycznych}

Zmiany ogniskowe umiejscowione $\mathrm{w}$ wątrobie dzielą się na pierwotne oraz przerzutowe. Pierwotne charakteryzują się rozpoczęciem procesu w rejonie wątroby, natomiast nowotwory przerzutowe mają swój początek w innym narządzie.

Do zmian łagodnych zalicza się gruczolaki wątrobokomórkowe, ropnie, torbiele i naczyniaki. Zmiany złośliwe wątroby to przede wszystkim raki - głównie rak z komórek wątrobowych. Znacznie rzadziej diagnozowane są w tym regionie pierwotne mięsaki, śródbłoniaki czy potworniaki złośliwe [8].

Gruczolak - występuje częściej u kobiet. Może być wynikiem stosowania przez długi czas antykoncepcji hormonalnej (poprzez wzrost poziomu estrogenów). W badaniu TK gruczolak cechuje się niższym sygnałem w stosunku do tkanek otaczających - jest hipodensyjny. W badaniu MRJ zmiana ulega wzmocnieniu w obrazach T2 - zależnych oraz osłabieniu w sekwencjach T1 - zależnych. Niekiedy guz znajduje się w torebce.

Naczyniak jamisty - to przykład zmiany łagodnej. W badaniu USG ognisko wykazuje wzmożony sygnał i ma okrągły kształt. W badaniach TK wygląda jak zmiana hipointensywna. Po wprowadzeniu kontrastu wzmacnia się. W MRJ naczyniak jest widoczny w następujący sposób: sekwencje T1 - zależne uwidaczniają naczyniaka w formie ogniska hipointensywnego, natomiast sekwencje T2 - zależne prezentują go jako strukturę o silnym, wzmożonym sygnale.

Rak z komórek wątrobowych może występować jako pojedyncze ognisko, lub jako ogniska mnogie. Zwykle cechuje się bogatym unaczynieniem. Wykazuje skłonność do tworzenia przerzutów do kości oraz do płuc, co może być związane z jego bliskim ulokowaniem względem tych narządów. Marskość wątroby jest czynnikiem, który podwyższa ryzyko wystąpienia tego nowotworu złośliwego [9]. W badaniu USG nowotwory złośliwe z komórek wątrobowych mogą prezentować się jako ogniska izoechogeniczne bądź hiperechogeniczne. Metoda Dopplera daje dodatkowe informacje na temat unaczynienia guza. W trakcie tomografii komputerowej przed podaniem kontrastu rak jest hipodensyjny. Wynika to z obecności tkanki tłuszczowej w obrębie nacieku oraz krwi. Po podaniu kontrastu może być widoczne wzmocnienie w miejscu usytuowania guza. W MRJ pierwotny nowotwór wątroby w sekwencji T - 2 zależnej jest hiperintensywny. Hipointensywne są duże ogniska w obrazach T1 - zależnych.

Rak z komórek żółciowych zazwyczaj występuje jednoogniskowo. Jest słabiej unaczyniony od raka z komórek wątroby i zwykle rozwija się w pobliżu wnęki. Może powodować zablokowanie odpływu żółci (tzw. zastój żółci).

Przerzuty zlokalizowane w wątrobie stanowią 90\% wszystkich złośliwych nowotworów wątroby. Najczęściej wywodzą się z raka jelita grubego oraz odbytnicy, a także żołądka oraz trzustki [10].

\section{Prezentacja procedur obrazowania TKjamy brzusznej na terenie dwóch wybranych Zakładów Diagnostyki Obrazowej}

Sposób wykonywania badań TK jest zależny od sprzętu oraz oprogramowania na jakim pracuje zespół, a także od procedur przyjętych na terenie wybranego zakładu.

W Szpitalu Wojewódzkim w Poznaniu dostępny jest aparat GE Healthcare. Najpierw wybierany jest obszar badania - w celu dokładnego zobrazowania wątroby elektroradiolodzy używają zakładki do badania jamy brzusznej lub jamy brzusznej z miednicą. Procedura obrazowania wątroby wykonywana jest w oparciu o protokół do badania trójfazowego. Grubość skanowanej warstwy w tym badaniu wynosi 2,5 mm. Kontrast podawany jest za pomocą strzykawki automatycznej do żyły łokciowej w okolicy przedramienia. Najpierw przeprowadza się badanie bez kontrastu, następnie podaje się kontrast. W momencie zauważenia napływającego kontrastu do naczynia przy wcześniejszym wrysowaniu ROI’a (ang. Region of Interests - obszar zainteresowania) rozpoczyna się skanowanie po kontraście - czyli faza tętnicza. Po 30 sekundach aparat na nowo skanuje obszar i uwidacznia się faza żylna. Czasami zlecane jest przez radiologa wykonanie fazy opóźnionej.

W Szpitalu Uniwersyteckim nr.1 w Bydgoszczy stosuje się różne schematy do badania jamy brzusznej. Wybór protokołu zależy od badanego narządu. Badanie wątroby wykonywane jest za pomocą aparatu firmy 
Siemens lub Philips. Protokół wygląda następująco: zakres skanowania od przepony do talerzy biodrowych. Skanowanie pacjenta odbywa się co $2 \mathrm{~mm}$. Wykonywane są odpowiednio fazy: przed kontrastem oraz po kontraście w następujących czasach:

(a) Po 30 sekundach od rozpoczęcia podania

(b) Po 70 sekundach po rozpoczęciu podania

(c) Po 240 sekundach od rozpoczęcia podania

(d) W przypadku naczyniaka - skanowanie odbywa się dodatkowo po 15 minutach od rozpoczęcia podania. Decyzję o fazie opóźnionej podejmuje radiolog.

\section{Podsumowanie}

TK to cenne badanie, wykorzystywane do wykrywania zmian ogniskowych w wątrobie. Cechuje się wysoką swoistością oraz czułością. Podanie środka kontrastowego w trakcie procedury TK ułatwia radiologowi podjęcie decyzji o rozpoznaniu - zmiany ogniskowe zazwyczaj ulegają silnemu wzmocnieniu, co odróżnia je od otoczenia. Badanie TK jest nieco tańsze od procedury MRJ, co również predysponuje do częstszego obrazowania tą techniką. TK daje większy zakres informacji od USG - określa nie tylko wielkość i charakter zmiany, ale również jej rozległość oraz stosunek do sąsiednich tkanek. Charakteryzuje ją wyższa rozdzielczość kontrastowa. Zastosowany środek kontrastowy prezentuje bogate bądź słabe unaczynienie guza. W efekcie końcowym tomografia pomaga w ustaleniu rozpoznania, które wpływa w sposób istotny na kwalifikację chorego do leczenia.

\section{Konflikt interesu / Conflict of interest}

Nie występuje/ None

\section{Etyka / Ethics}

Treści przedstawione w artykule są zgodne z zasadami Deklaracji Helsińskiej, dyrektywami EU oraz ujednoliconymi wymaganiami dla czasopism biomedycznych.

\section{Piśmiennictwo/ References}

[1] Sąsiadek M. Wytyczne dla lekarzy kierujących na badania obrazowe. Krajowe Centrum Ochrony Radiologicznej 2015; 7: 3-23.

[2] Onkologia.org.pl

[3] Krzakowski M, Zieniewicz K, Habior A. Rak wątrobowo komórkowy - rozpoznanie i leczenie. Onkol. Prakt. Klin. 2009; 5: 125-140.

[4] Kordek R, Jassem J, Krzakowski M, Jeziorski A. Onkologia. Podręcznik dla studentów i lekarzy. Via Medica 2016; 4: 185-194.

[5] Szczeklik A, Gajewski P. Choroby wewnętrzne. Medycyna Praktyczna 2009; 1: 542-552.

[6] Hrynkiewicz A. Z, Rokita E. Fizyczne metody diagnostyki medycznej i terapii. Wydawnictwo Naukowe PWN 2013.

[7] Małkowski P, Wasiask D, Czerwiński J. Rekomendacje dotyczące rozpoznania i leczenia raka wątrobowokomórkowego. Med. Sci. Review Hepatologia 2009; 4: 27-33.

[8] [Kordek R, Jassem J, Krzakowski M, Jeziorski A. Onkologia. Podręcznik dla studentów i lekarzy. Via Medica 2016; 4: 185-194.

[9] Małkowski P, Wasiak D, Czerwiński J. Opcje terapeutyczne w raku wątrobowokomórkowym. Gastroenterol. Pol. 2009; 16: 333-338.

[10] Pruszyński B. RADIOLOGIA. Diagnostyka obrazowa RTG, USG, TK, MR i medycyna nuklearna. PZWL 2005; 2: 304-319. 